\title{
18-8 ステンレス鋼の燒結材についで
}

椙山正 孝** 鈴木 壽**

Masataka Sugiyama and Hisashi Suzuki : On Sintering Stainless Steel Powder. Experiments on sintering 302 type stainless steel powder specimens prepare 1 by iniergranular corrosion and in addition, on those made by mechanical crashing were carried out. The density, the hardness, the tensile properties and the structures of compacts pressed at 30 to 60 tsi, sintered at 1100 to $1350^{\circ}$ for 1 to $5 \mathrm{hrs}$ and also resintered at $1200^{\circ}$ for $1 \mathrm{hr}$ after cold rolling of 10 to 40 per cent reduction in thickness were investigated.

(Received October 30, 1957)

\section{I. 緒 言}

周知のごとく 18-8 ステンレス鋼は被切剤性が不良で, 各種精密機械部品に切削加工寸ることが困難である.また 各種フィルター材に 18-8 ステンレス鋼を利用できれば都 合のよい場合がある.これらの問題を解決する一手段とし て粉末冶金法がある.この方法では形状による制限がほと んどなく，高比重材または有孔材などの量産が容易であ り，乙かも歩留が高いことなど種々の利点を有するので, これら製品の製造はとくに有望である.

他方 18-8 ステンレス鋼の粉末冶金は，合金粉末の製造 がかなり困難であること，さらに所望の粉末が得られたに しても成型，焼結性が劣ることなどの理由により，ほとん ど研究がなされていないようである.アトマイズ粉による 二三の外国報文はあるが，わが国に和いてはこの種の研究 が皆無である.

以上の理由から，粒間腐蝕法による試作粉末を用いて 18-8 ステンレス鋼の焼結に関する基礎研究を行い，焼 結 材または焼結加工材の諸性質に拉よぼす成型, 焼結諸条件 の影響を詳細に検討した.

\section{II. 試料および実験方法}

試料粉として個々の粉末の混合粉を用いれば，焼結温度 を高め焼結時間を著しく長くしなければならず，実用性に そしいために合金粉末を試料粉とした. 主として粒間腐蝕 法による粉末を用いたが，機械的に粉砕した粉末も併用し た.

粒間腐蝕法 (intergranular corrosion, I.C. 法)によ る粉末製法の詳細(1)は省略するが，执よそ次の工程によつ て試作製造した. 溶製, 鍛造後約 $40 \%$ 冷間圧延し，これ を約 $700^{\circ} \times 20 \mathrm{hr}$ センシタイズ処理を施し，十分脆弱にな つたものを軽く粉䂗して作つた. 粉砕直前の十分脆化せる ものの顕微鏡組織をPhoto.1 に示した. これより粒間腐蝕 法による粉末の粒度は, センシタイズ処理後の結晶粒度と 対応して扣り, 従つて粒形はほほ球形に近い。この粒度分 布は以下に示すが，粒度がセンシタイズ処理後の結晶粒度 と対応することは，センシタイズ処理前の冷間圧延度，ま

**. 東京大学工学部冶金学教室

* 1957 年 4 月本会東京大会に発表

（1）椙山, 鈴木 (高)：1955 年 10 月本会金沢大会に発表

たはセンシタイズ条件などにより粒度分布を変化せしめ5 るわ故ある. I.C.法による粉末の分析值は Table 1 の

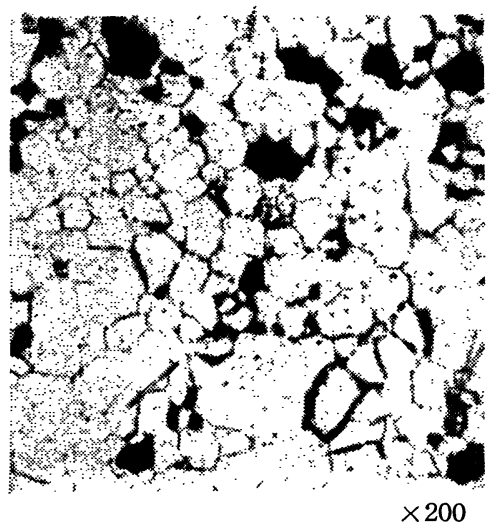

Photo. 1 Microstructure of stainless steel fully intergranually corroded. As polished.

Table 1 Chemical analysis of stainless steel powder (\%).

\begin{tabular}{c|c|c|c|c}
\hline \hline $\mathrm{C}$ & $\mathrm{Si}$ & $\mathrm{Mn}$ & $\mathrm{Cr}$ & $\mathrm{Ni}$ \\
\hline 0.11 & 1.09 & - & 18.34 & 8.15 \\
\hline
\end{tabular}

Table 2 Sieve analysis of stainless steel powders (\%).

\begin{tabular}{r|c|c}
\hline Mesh size & $\begin{array}{l}\text { Powder from inter- } \\
\text { granular corrosion }\end{array}$ & $\begin{array}{l}\text { powder from me- } \\
\text { chanical crashing }\end{array}$ \\
\hline$-100+150$ & 0 & 30 \\
$-150+200$ & $8 \sim 9$ & 24 \\
$-200+280$ & $45 \sim 55$ & 28 \\
$-280+325$ & $26 \sim 35$ & 9 \\
-325 & $11 \sim 12$ & 9 \\
\hline
\end{tabular}

2 には両粉末の粒度分布を示す. ここに I.C. 粉は製造さ れたままであるが, - 200〜+325 mesh の微粉末が約 $80 \%$ 以上を占め充媜密度は $4.7 \mathrm{~g} / \mathrm{cc}$ の高比重を示す. 他方 M.C. 粉は粒度調整を行つたが，な特粗粉であり充填密度 は約 $3.3 \mathrm{~g} / \mathrm{cc}$ である.これより M.C. 粉の製法は簡便法 ではあるが，粉末の性能は比較的に劣つているようであ る.

次に実験方法を述べる. 両種粉末とも使用直前に 1000 $1050^{\circ}$ にて $1 \mathrm{hr}$ 高純乾燥水素炉を用いて焼鈍・還元した 
この粉末の成型は，粉量 ひ g そ $0 \times 10 \mathrm{~mm}$ の表面寸法に 30〜60 tsi の各成型圧にて油圧プレスを用いて行つた. こ の際の型の潤滑阂は流動パラフィンである. 次に焼結は同 上の高純水素炬にて $1100 \sim 1350^{\circ}, 1 \sim 5 \mathrm{hr}$ の種々の条件 で行つた.な拈 $1200^{\circ} \times 1 \mathrm{hr}$ の焼結条件に対しては，焼結 材を 10〜 40％冷間圧延し再焼結の実験も行つた. そして いずれの場合も，焼結材の諸性質すなわち焼結比重，収縮 率，硬度，引張性質特よび顕微鏡組織などを調べ，これら に拉よぼす成型，焼結，冷間圧延条件などの諸影響を明ら かにした. な括 I.C. 粉と M.C. 粉との比較はもちろん， 外国報文に基くアトマイズ粉などとの比較検討も行つた.

さて本試験では水素炉の水素の純化に特に留意した.こ れは合金ステンレス鋼粉末の成型，焼結性が不良で，良好 な焼結材が得られにくい理由の一つとして，粉末表面の酸 化物なかんずく還元困難な Cr の酸化物が考兄られるか らである. そこで粉末の還元処理または焼結時に和いて は，十分 Cr の酸化物が還元されるような炉の設計を行つ た.工業用水素の純化方式打よび炉の構造の略図は Fig.1 の如くで, 炉は二重となし中央の管材としては金属管も考 えられるが，ここでは十分緻密かつ耐熱強度，耐熱衝撃性 のある耐火物管(西村工業製 N.C. 管) を使用した. この結 果は例光ば黑色を呈する粉末の焼結材飞約 $1100^{\circ} \times 15 \mathrm{~min}$ 以上の数結にて完全に金属光沢を示すょうになる.

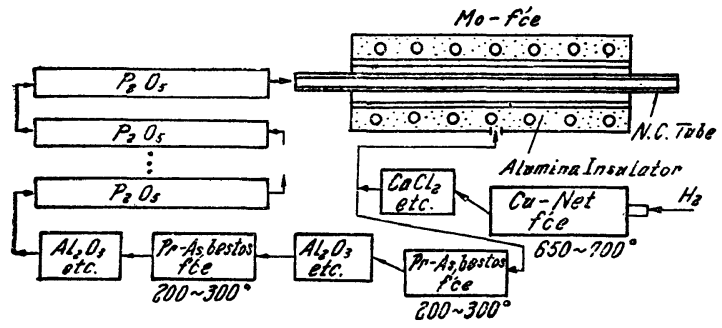

Fig. 1 Schematic drawing of sintering furnace and purification system of hydrogen.

\section{III. 実験結果および考察}

まず焼結材の比重, 収縮率物よび硬度などに扣よぼす成 型圧の影響を Fig.2 に示す.これより以下のことが判る. 比重は成型比重も併記したが，I.C. 粉の方がM.C. 粉より も成型・焼結性が著しく優れて括り，前者では約 40 tsi の 成型圧にて $6.5 \mathrm{~g} / \mathrm{c}$ の焼結比重である. また両比重とる 前者粉末では成型圧の増加と共にかなり増加するが, IM.C. 粉ではほとんど増加しない，試片の長さ方向を以て示した 収縮率は，I.C. 粉の方がやや大であるが，注注同一傾向に ある. $\mathrm{R}_{\mathrm{B}}$ 硬度值は両粉とも成型圧の増加と共に漸増し， これは主として焼結比重値に対応している.

さてアトマイズ粉を用いての A.H.Grobe(2)(3) ら执よ

(2) A.H. Grobe, G. A. Roberts : J. Metals, 3(1951), 125.

(3) A.H. Grobe, G. A. Roberts : Rep. of VanadiumAlloys Steel Company, No.3(1952).

び H.S.Kalishら(4) の結果では, 40 tsi の成型圧, $1200^{\circ}$ $\times 1 \mathrm{hr}$ 程度の同上の条件下にて，焼結比重は約 $5.6 \sim 5.9$ g/cc である. また粒間腐蝕粉末での F. Benesovskyら(5)

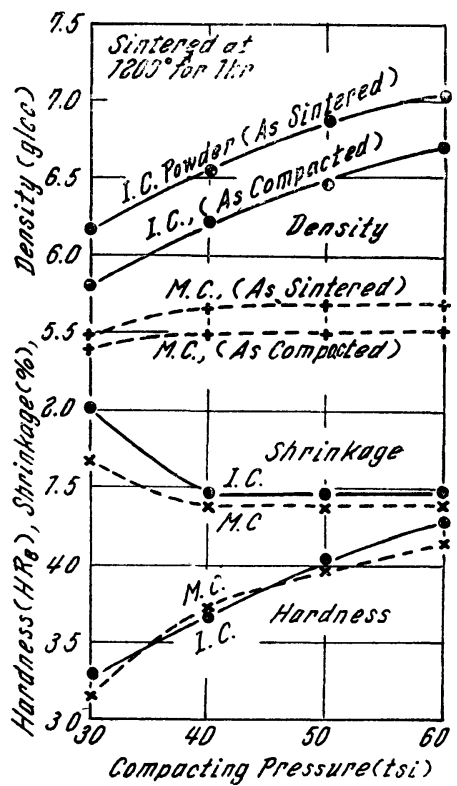

Fig. 2 Effect of compacting pressure on density, shrinkage and hardness of stainless steel compacts. The curves refer to compacts from powder prepared by intergranular corrosion (I.C.) and by mechanical crashing(M. C). All, sintered at $1200^{\circ}$ for 1 hr in extra pure hydrogen.

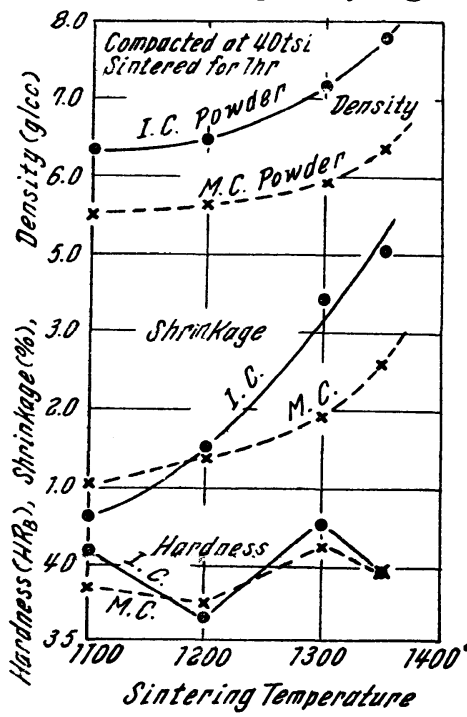

Fig. 3 Effert of sintering temperature on density, shrinkage and hardness of stainless steel compazts. All, compacted c:t $40 \mathrm{tsi}$ and sintered for $1 \mathrm{hr}$ in extra pure hydrogen.

(4) H.S. Kalish, E. N. Mazza : J.Metals, 7(1955), 304.

(5) F.Benesovsky, W. Hotop und F.Frehn : Plansceberichte für Pulvermetallurgie, 3 (1955), 57.

の結果では, 真空 㸁結を行つている が $626 \sim 6.43 \mathrm{~g} / \mathrm{cc}$ である.これら諸 結果より本試験の I.C. 粉による性 能は, アトマイズ 粉に比較すればも ちろんのこと， F. Benesovsky 5 の結果よりる優れ ている.これは主 として水素炉の水 素の純度に依存す るようである.他 方 M. C. 粉はアト マイズ粉とほ滦同 等と解される。

以上のごとく I. C. 粉の優れて いることは, 以下 も同様であるが両 粉末間の粒度分 布, 粒形などの相 違または内藏酸化 物の有無などから 考えられ上5。

次に焼結温度の 影響を Fig.3 に 示す. 成型圧は前 実験結果からまた 工業的に型の寿命 の点から $40 \mathrm{tsi}$ 一 定とし，烸結時間 $1 \mathrm{hr}$ にてしらべ た. 比重は温度の 上昇と共に急增し I.C. およびM.C. それぞれ $1300^{\circ}$ の 烧結にて 7.2 执よ び $6.0 \mathrm{~g} / \mathrm{cc}$ 程度と なる. 収縮率も比 重と同じ傾向にお り $1300^{\circ}$ にてI.C. 粉は約 $3 \%$ であ る. 硬度变化は両 粉とも同一傾向に あつて，温度に刘 政 
し平滑な変化を示さない，そして緻密化に伴う硬度の上昇 は I.C. 粉にてやや高い.

Photo. 2 には上記の場合の I.C. 粉について, 組織に㸮

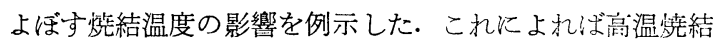
材ほど，粒間に $\propto$ 晶の出現の多いことがとくに目立つ。ま たこの $\boldsymbol{a}$ 晶は以下の焼結時間の影響の項でその組織を割愛 しているが，燒結時間の長いもの汪ど多い：これ恃本試料 がSi を含有していることに主因があり，筷結中の脱炭の 影響も考㝋られる.

(a)
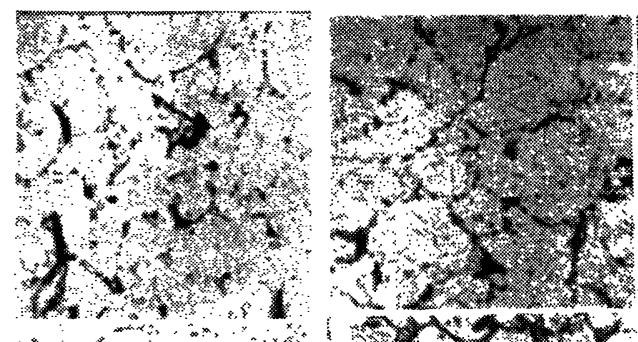

(b)
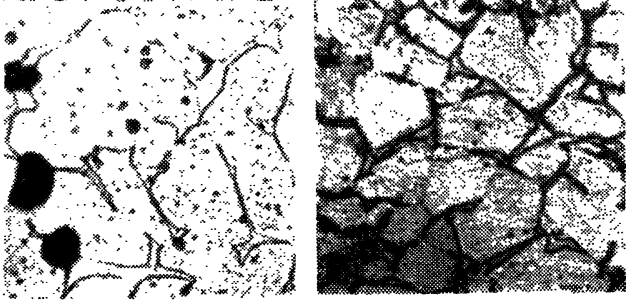

$\times(100 \times 1.7)$

Photo. 2 Microstructures of stainless steel compacts sintered for $1 \mathrm{hr}$. at $1100^{\circ}$ (a), $1200^{\circ}$ (b), $1300^{\circ}$ (c) and $1350^{\circ}$ (d) in atomospher of pare hydrogen. Compacting pressure, 40 tsi; Etchant, mixed acid of $\mathrm{HCl}$ and $\mathrm{HNO}_{3}$.

次に烍結時間の影響を Fig.4 亿示す。あまり高温での 燒結は実用性に乏しい故， $1200^{\circ}$ 焼結の場合を例示し，M.

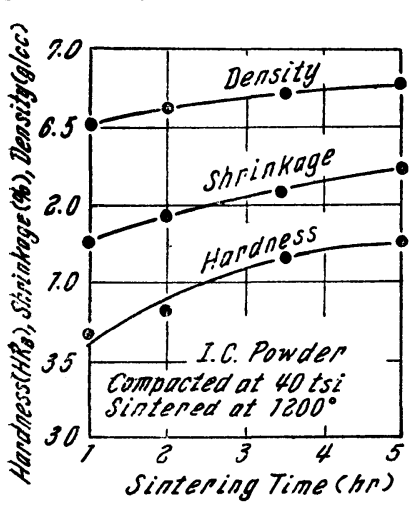

Fig. 4 Effect of sintering time on density, shrinkage and hardness of stainless steel compacts. Compacted at 40 tsi and sintered at $1200^{\circ}$ in pure hydrogen.

知られる. まずフィルター材などの有孔材の焼結の場合

(6) J.Wulff: Powder Metallurgy, ASM, Cleveland, (1942), 137.

は，M.C. 粉またはアトマイズ粉よりも一層有効ですろう I.C. 粉を用いれば, 成型圧は約 30 tsi 以下, 暁結温度招 よそ $1100^{\circ}$ の製造条件にあることである. また機峨部品用 材の場合は通常焼結比重は $6.5 \mathrm{~g} / \mathrm{cc}$ 以上，そして $7.0 \mathrm{~g} / \mathrm{cc}$ 前後が要求されるので, I.C. 粉であれば成型圧 $40 \mathrm{isi} に$ 対し拉よそ $1200^{\circ} \times 1 \mathrm{hr}$ 以上の尭結条件を選べばよいこと になる、ただし微少量のBなどの添加により焼結条件の低 下を図り得る場合は別である.

さて長時間焼結よりも高温焼結の方が, 高比重材を得る のに有利であることをのべたしつて $1200^{\circ}$ 以上の高温焼 結ば，一つには既述の耐火物管の寿命の点からかなりの困 （c）難があるように思われる. このため次に再燒結材の性質を 検討することにした.

烍結材の比重を高め，その機械的性質を向上さすために は，一般に焼結後加工してさらに再燒結を行うが，本試験 (d)

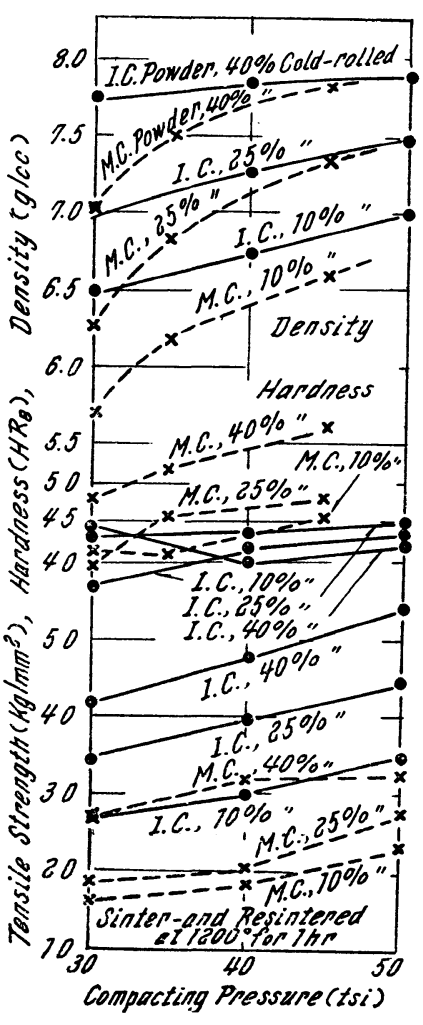

Fig. 5 Effect of resintering after sintering and cold rolling on stainless steel compacts. Sinter and resintering condition, $1200^{\circ}$ $\times 1 \mathrm{hr}$ in pure hydrogen.
での加工は簡便のため 冷圧延とした.さてて の際の冷压延は種々の 条件のものに対乙約 $60 \%$ 可能であつたの で, 焼結条件を $1200^{\circ}$ $\times 1 \mathrm{hr}$ 一定となし，成 型圧を変化せしめ，冷 圧延度を 10,25, $40 \%$ とした場合をしらべ た.これを Fig. 5 に 示す.これによれば比 重は成型圧大で山るほ ど，冷压延度大である ほど増加し, 压延度大 となれば圧力の影響が 減ずる.な特同図に M.C. 粉を併記 した が, この際も I.C. 粉 との優劣は明白であ る. そして I.C. 粉で はいずれの圧延度にて も成型圧の影響が少く 高比重となるが, M.C. 粉では 40 \% 冷圧延度 にても圧力の影響が著 しい.換言すれば I.C. 粉では, 所定比重材を 得るのに成型圧を低めることがでさ，圧力の多少の変動は 影響がない。これは大きな利点である.そしてこのI.C. 粉にて再焼結比重を $6.5 \mathrm{~g} / \mathrm{cc}$ とするには, 上記の中位の 焼結条件であつても圧力 30 tsi 以上，冷 圧延度 $10 \%$ 以 
上で足り, 本試験での実測理論比重 $7.85 \mathrm{~g} / \mathrm{cc}$ (一般に は 7.65〜7.91 g/cc）に達せしむるには圧力 $40 \mathrm{tsi}$, お

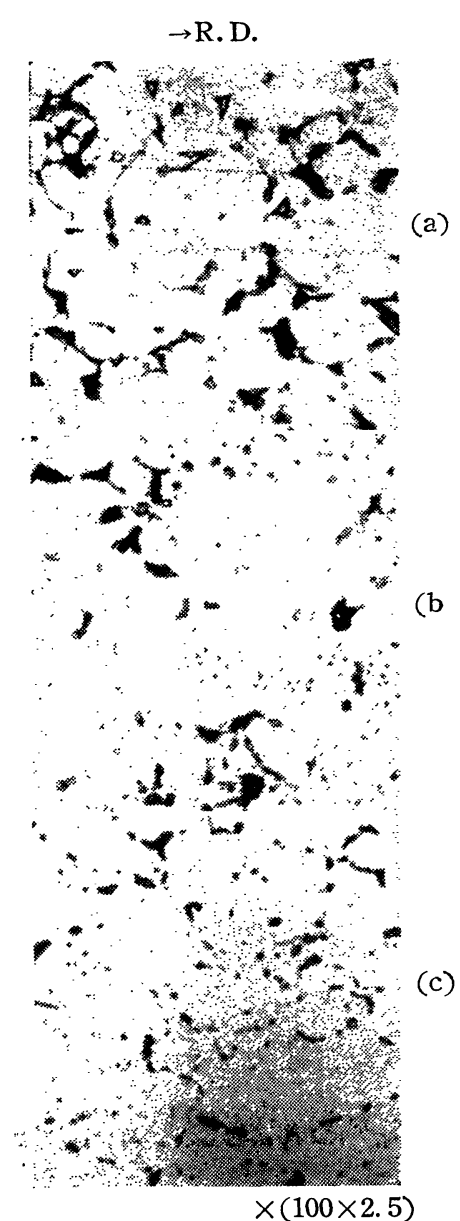

Photo. 3 Structures of stainless steel compacts resintered. Compacting pressure, 40 tsi; Sinter- and resintering condition, $1200^{\circ} \times 1 \mathrm{hr} ; \mathrm{a}, \mathrm{b}$ and c, cold-rolled 10,25 and $40 \%$ respectively; Etchant, mixed acid in glycerol.

よそ $40 \%$ 泠圧延 度以上で可能で ある・これは既述 の高温焼結よりも 有利であろう。

次に再焼結材の 硬度は内藏酸化 物によるためか M.C. の方が概し て高く, I.C.では 40〜 $45 \mathrm{HR}_{B}$ であ る. 引張強さは比 重曲線とほほ併行 して向上する.そ して成型圧 $40 \mathrm{tsi}$, 冷圧延度和よそ $25 \%$ 以上にて引 張強さは約 40 $\mathrm{kg} / \mathrm{mm}^{2}$ 以上を 示す.な抔园し なかつたが，引張 強さと比重とはほ ぼ直線関係にあ る. 伸びの值も図 示しなからたが, これも比重が大で あるほど改善さ れ, 引張強さ約 $40 \mathrm{~kg} / \mathrm{mm}^{2}$ にて 15〜20\%である. これら弓涱性質は 加工材に比しておよばないが，必要に応じて長時間焼結ま
たは既述の粒度分布による改善法があろう.Photo.3 は I.C. 粉について示した組織例である.10〜 40\%の冷圧延 度による組織差はほとんどなく粒間に $\boldsymbol{a}$ 晶がわずかに見ら れる.な和これは板の圧延方向に平行な断面での組織であ る.

IV. 総 括

18-S ステンレス鋼の焼結材に関する基礎研究を，主と して粒間腐蝕粉末を用いて行い，执よそ以下の諸結果が得 られた。

（1）焼結用䨌囲気として $\mathrm{H}_{2}$ 気流を用いたが，焼結炉の 設計には特に注意を要する。矤結用耐火物管は十分適当な ものでなければならない。

（2）粒間腐蝕法による粉末の成型，焼結性は相当に良 く,アトマイズ粉などの結果より優れている.そして焼結 比重 $6.5 \mathrm{~g} / \mathrm{cc}$ 以上は扣よそ成型圧 $40 \mathrm{tsi}, 1200^{\circ} \times 1 \mathrm{hr}$ 以 上の焼結にて達せられる。

（3）焼結材の諸性質は特に焼結温度の上年によつて改善 せられる. 収縮率は通常 2〜3\%である.

(4) 次に再焼結材 $\left(1200^{\circ} \times 1 \mathrm{hr}\right.$ 焼結) についてである が, 再焼結比重 $6.5 \mathrm{~g} / \mathrm{cc}$ 以上は技よそ成型圧 $30 \mathrm{tsi}$, 冷 生延 $10 \%$ 以上にて達せられ，成型圧 $40 \mathrm{tsi}, 40 \%$ 冷圧延 にてほぼ理論比重に達する。

(5) 再焼結材の $\mathrm{R}_{\mathrm{B}}$ 硬度值は 40 45, 引張強さは理論 比重の約 $90 \%$ 以上にて約 $40 \mathrm{~kg} / \mathrm{mm}^{2}$ 以上，伸び 15 $20 \%$ を示す.

(6) 顕微鏡組織は高温長時間烸結のものほど粒間に $\boldsymbol{\alpha}$ 晶 が多く見られる.

（7）以上は粒間腐蝕粉についての大略であるが，例衤ば その粒度分布の改善によりさらに性能の向上を期待出来よ 5 .

（8）比較のために機械的粉砕粉も試験したが，これによ る焼結材の性質はかなり低いものがある.

最後に本研究の遂行にあたり，焼結用酎火物管について 種々御援助をいただいた西村工業株式会社 林和夫氏に 深甚の謝意を表する. 